\title{
PELAKSANAAN PENILAIAN PEMBELAJARAN TEMATIK DI SD PURWANTORO 1 KOTA MALANG DAN MI NURUL ISLAM \\ TAJINAN KABUPATEN MALANG
}

\author{
Dyah Worowirastri Ekowati*
}

\begin{abstract}
Educational assessment standards were prepared in order to complete the assessment standards. This study aims to describe the ability of teachers in assessment of thematic learning. Based on the results of the research, which shows the performance evaluation based on the curriculum 2013, has not been fully implemented by Shanta 1 SD Negeri Malang and MI Nurul Islam sub district of Tajinan. The obtained data will be very useful for determining measures or policies relating to the assessment standards, which in turn is expected to improve the quality of the school.
\end{abstract}

Keywords: Assessment, Thematic Learning

\begin{abstract}
Abstrak
Standar penilaian pendidikan disusun dalam rangka menyiapkan standar penilaian. Penelitian ini bertujuan untuk mendeskripsikan kemampuan guru dalam melakukan penilaian pembelajaran tematik. Berdasarkan hasil dari penelitian, menunjukkan pelaksanaan penilaian yang didasarkan pada kurikulum 2013 ini belum sepenuhnya dilaksanakan oleh SD Negeri Purwantoro 1 Kota Malang dan MI Nurul Islam Kec. Tajinan. Data yang diperoleh akan sangat berguna untuk menentukan langkah atau kebijakan terkait dengan standar penilaian, yang pada akhirnya diharapkan dapat meningkatkan kualitas sekolah.
\end{abstract}

Kata Kunci: Penilaian, Pembelajaran Tematik

\section{A. Pendahuluan}

Menurut Undang-Undang Nomor 20 Tahun 2003 tentang Sistem Pendidikan Nasional,Pasal 1 angka 1 menyatakan bahwa "pendidikan adalah usaha sadar danterencana untuk mewujudkan suasana belajar dan proses pembelajaran agar peserta didik secara aktif mengembangkan potensi dirinya untuk memiliki kekuatan spiritual keagamaan, pengendalian diri, kepribadian, kecerdasan, akhlak mulia, serta keterampilan yang diperlukan dirinya, masyarakat, bangsa dan negara".

Selanjutnya, Pasal 3 menegaskan bahwa pendidikan nasional"berfungsi mengembangkan kemampuan dan membentuk watak sertaperadaban bangsa yang bermartabat dalam rangka mencerdaskan kehidupan bangsa, bertujuan untuk berkembangnya potensi peserta didik agar menjadimanusia yang beriman dan bertakwa kepada Tuhan Yang Maha Esa, berakhlak mulia, sehat, berilmu, cakap, kreatif, mandiri, dan menjadi warga negara yang demokratis serta bertanggung jawab (dalam Permendikbud No. 66 th 2013 tentang Standar Penilaian, 2013).

* Dyah Worowirastri Ekowati adalah Dosen Prodi PGSD Universitas Muhammadiyah Malang 
Dalam rangka mewujudkan hal tersebut di atas, maka fungsi dan tujuan pendidikan nasional menjadi parameter utama untuk merumuskan Standar

Nasional Pendidikan. Standar Nasional Pendidikan "berfungsi sebagai dasar dalam perencanaan, pelaksanaan, dan pengawasan pendidikan dalam rangka mewujudkan pendidikan nasional yang bermutu". Standar Nasional Pendidikan terdiri atas 8 (delapan) standar, salah satunya adalah Standar Penilaian yang bertujuan untuk menjamin:a.perencanaan penilaian peserta didik sesuai dengan kompetensi yang akan dicapai dan berdasarkan prinsip-prinsip penilaian; b.pelaksanaan penilaian peserta didik secara profesional, terbuka, edukatif, efektif, efisien, dan sesuai dengan konteks sosial budaya; dan c.pelaporan hasil penilaian peserta didik secara objektif, akuntabel, dan informatif.

Standar penilaian pendidikan ini disusun sebagai acuan penilaian bagi pendidik, satuan pendidikan, dan pemerintah pada satuan pendidikan untuk jenjang pendidikan dasar dan menengah. namun, berdasarkan hasil penilaian pada kegiatan penelitian yang berjudul "Model Pembelajaran Pendidikan Karakter Terintegrasi Pada Pembelajaran Tematik Di SD Muhammadiyah 9 Kota Malang" tahun 2012-2013 (Setyaningrum, dkk, 2012)dan pengabdian "Pelatihan Penerapan Pembelajaran Tematik Bagi Guru-Guru Kelas1-3SD Muhammadiyah 9 Malang" tahun 2009 (Cholily, dkk, 2009), diketahui bahwa SD muhammadiyah belum memiliki acuan mengenai penilaian pembelajaran tematik.

Pada pelaksanaan penilaian pembelajaran tematik di sekolah, salah satunya di MI Nurul Islam Tajinan, para guru hanya mengambil soal-soal penilaian dari LKS atau buku pegangan Guru. Hal ini dirasa mengkhawatirkan, karena dalam beberapa pendampingan dalam kegiatan pengabdian yang dilakukan sebelumnya, ditemukan beberapa soal penilaian yang tidak sesuai dengan indikator pembelajaran.

Berdasarkan dari uraian tersebut maka perlu diketahui lebih mendalam pelaksanaan penilaian pembelajaran tematik di SDNegeri Purwantoro 1 dan MI Nurul Islam Tajinan. Informasi mendalam mengenai pelaksanaan penilaian yang diperoleh akan sangat berguna untuk menentukan langkah atau kebijakan terkait dengan standar penilaian, yang pada akhirnya diharapkan dapat meningkatkan kualitas sekolah.

\section{B. Kajian Pustaka}

\section{Standar Penilaian Pendidikan}

Undang-Undang Nomor 20 Tahun 2003 tentang Sistem Pendidikan Nasional,Pasal 1 angka 1 menyatakan bahwa "pendidikan adalah usaha sadar danterencana untuk mewujudkan suasana belajar dan proses pembelajaran agarpeserta didik secara aktif mengembangkan potensi dirinya untuk memilikikekuatan spiritual keagamaan, pengendalian diri, kepribadian, kecerdasan, akhlak mulia, serta keterampilan yang diperlukan dirinya, masyarakat, bangsadan negara". Selanjutnya, Pasal 3 menegaskan bahwa pendidikan nasional"berfungsi mengembangkan kemampuan dan membentuk watak sertaperadaban bangsa yang bermartabat dalam rangka mencerdaskan kehidupanbangsa, bertujuan untuk berkembangnya potensi peserta didik agar menjadimanusia yang beriman dan bertakwa kepada Tuhan Yang Maha Esa, 
berakhlak mulia, sehat, berilmu, cakap, kreatif, mandiri, dan menjadi warganegara yang demokratis serta bertanggung jawab".

Fungsi dan tujuan pendidikan nasional tersebut menjadi parameter utamauntuk merumuskan Standar Nasional Pendidikan. Standar Nasional

Pendidikan "berfungsi sebagai dasar dalam perencanaan, pelaksanaan, danpengawasan pendidikan dalam rangka mewujudkan pendidikan nasional yang bermutu". Standar Nasional Pendidikan terdiri atas 8 (delapan) standar, salahsatunya adalah Standar Penilaian yang bertujuan untuk menjamin perencanaan penilaian peserta didik sesuai dengan kompetensi yang akan dicapai dan berdasarkan prinsip-prinsip penilaian;pelaksanaan penilaian peserta didik secara profesional, terbuka, edukatif, efektif, efisien, dan sesuai dengan konteks sosial budaya; dan pelaporan hasil penilaian peserta didik secara objektif, akuntabel, dan informatif.

\section{Pengertian Standar Penilaian Pendidikan}

Standar Penilaian Pendidikan adalah kriteria mengenai mekanisme,prosedur, dan instrumen penilaian hasil belajar peserta didik.Penilaian pendidikan sebagai proses pengumpulan dan pengolahaninformasi untuk mengukur pencapaian hasil belajar peserta didikmencakup: penilaian otentik, penilaian diri, penilaian berbasis portofolio,ulangan, ulangan harian, ulangan tengah semester, ulangan akhirsemester, ujian tingkat kompetensi, ujian mutu tingkat kompetensi, ujiannasional, dan ujian sekolah/madrasah, yang diuraikan sebagai berikut.

1. Penilaian otentik merupakan penilaian yang dilakukan secara komprehensif untuk menilai mulai dari masukan (input), proses,dan keluaran (output) pembelajaran.

2. Penilaian diri merupakan penilaian yang dilakukan sendiri oleh peserta didik secara reflektif untuk membandingkan posisi relatifnya dengan kriteria yang telah ditetapkan.

3. Penilaian berbasis portofolio merupakan penilaian yang dilaksanakan untuk menilai keseluruhan entitas proses belajar peserta didik termasuk penugasan perseorangan dan/atau kelompok di dalam dan/atau di luar kelas khususnya pada sikap/perilaku dan keterampilan.

4. Ulangan merupakan proses yang dilakukan untuk mengukur pencapaian kompetensi peserta didik secara berkelanjutan dalam proses pembelajaran, untuk memantau kemajuan dan perbaikan hasil belajar peserta didik.

5. Ulangan harian merupakan kegiatan yang dilakukan secara periodik untuk menilai kompetensi peserta didik setelah menyelesaikan satu Kompetensi Dasar (KD) atau lebih.

6. Ulangan tengah semester merupakan kegiatan yang dilakukan oleh pendidik untuk mengukur pencapaian kompetensi peserta didik setelah melaksanakan 8 - 9 minggu kegiatan pembelajaran. Cakupan ulangan tengah semester meliputi seluruh indikator yang merepresentasikan seluruh KD pada periode tersebut.

7. Ulangan akhir semester merupakan kegiatan yang dilakukan oleh pendidik untuk mengukur pencapaian kompetensi peserta didik di akhir semester. Cakupan ulangan meliputi seluruh indikator yang merepresentasikan semua KD pada semester tersebut. 
8. Ujian Tingkat Kompetensi yang selanjutnya disebut UTK merupakan kegiatan pengukuran yang dilakukan oleh satuan pendidikan untuk mengetahui pencapaian tingkat kompetensi. Cakupan UTK meliputi sejumlah Kompetensi Dasar yang merepresentasikan Kompetensi Inti pada tingkat kompetensi tersebut.

9. Ujian Mutu Tingkat Kompetensi yang selanjutnya disebut UMTK merupakan kegiatan pengukuran yang dilakukan oleh pemerintah untuk mengetahui pencapaian tingkat kompetensi. Cakupan UMTK meliputi sejumlah Kompetensi Dasar yang merepresentasikanKompetensi Inti pada tingkat kompetensi tersebut.

10. Ujian Nasional yang selanjutnya disebut UN merupakan kegiatan pengukuran kompetensi tertentu yang dicapai peserta didik dalam rangka menilai pencapaian Standar Nasional Pendidikan, yangdilaksanakan secara nasional.

11. Ujian Sekolah/Madrasah merupakan kegiatan pengukuran pencapaian kompetensi di luar kompetensi yang diujikan pada UN, dilakukan olehsatuan pendidikan.

\section{Pembelajaran Tematik}

Sesuai dengan tahap perkembangan anak, karakteristik cara anak belajar, konsep belajar dan pembelajaran bermakna, maka kegiatan pembelajaran bagi anak kelas awl SD sebaiknya dilakukan dengan Pembelajaran tematik. Pengertian Pembelajaan tematik adalah pembelajaran tepadu yang menggunakan tema untuk mengaitkan beberapa mata pelajaran sehingga dapat memberikan pengalaman bermakna kepada siswa. Tema adalah pokok pikiran atau gagasan pokok yang menjadi pokok pembicaraan (Poerwadarminta, 1983).

Arti Penting Pembelajaran Tematik

Pembelajaran tematik lebih menekankan pada keterlibatan siswa dalam proses belajar secara aktif dalam proses pembelajaran, sehingga siswa dapat memperoleh pengalaman langsung dan terlatih untuk dapat menemukan sendiri berbagai pengetahuan yang dipelajarinya. Melalui pengalaman langsung siswa akan memahami konsep-konsep yang mereka pelajari dan menghubungkannya dengan konsep lain yang telah dipahaminya. Teori pembelajaran ini dimotori para tokoh Psikologi Gestalt, termasuk Piaget yang menekankan bahwa pembelajaran haruslah bermakna dan berorientasi pada kebutuhan dan perkembangan anak.

Pembelajaran tematik lebih menekankan pada penerapan konsep belajar sambil melakukan sesuatu (learning by doing). Oleh karena itu, guru perlu mengemas atau merancang pengalaman belajar yang akan mempengaruhi kebermaknaan belajar siswa. Pengalaman belajar yang menunjukkan kaitan unsurunsur konseptual menjadikan proses pembelajaran lebih efektif. Kaitan konseptual antar mata pelajaran yang dipelajari akan membentuk skema, sehingga siswa akan memperoleh keutuhan dan kebulatan pengetahuan. Selain itu, dengan penerapan pembelajaran tematik di sekolah dasar akan sangat membantu siswa, karena sesuai dengan tahap perkembangannya siswa yang masih melihat segala sesuatu sebagai satu keutuhan (holistik).

Beberapa ciri khas dari pembelajaran tematik antara lain: 1) Pengalaman dan kegiatan belajar sangat relevan dengan tingkat perkembangan dan kebutuhan anak usia sekolah dasar; 2) Kegiatan-kegiatan yang dipilih dalam pelaksanaan pembelajaran tematik bertolak dari minat dan kebutuhan siswa; 3) Kegiatan 
belajar akan lebih bermakna dan berkesan bagi siswa sehingga hasil belajar dapat bertahan lebih lama; 4) Membantu mengembangkan keterampilan berpikir siswa; 5) Menyajikan kegiatan belajar yang bersifat pragmatis sesuai dengan permasalahan yang sering ditemui siswa dalam lingkungannya; dan 6) Mengembangkan keterampilan sosial siswa, seperti kerjasama, toleransi, komunikasi, dan tanggap terhadap gagasan orang lain.

\section{Kurikulum SD}

\section{a. Pengertian Kurikulum}

Undang-Undang Nomor 20 Tahun 2003 tentang Sistem Pendidikan Nasional menyebutkan bahwa kurikulum adalah seperangkat rencana dan pengaturan mengenai tujuan, isi, dan bahan pelajaran serta cara yang digunakan sebagai pedoman penyelenggaraan kegiatan pembelajaran untuk mencapai tujuan pendidikan tertentu. Berdasarkan pengertian tersebut, ada dua dimensi kurikulum, yang pertama adalah rencana dan pengaturan mengenai tujuan, isi, dan bahan pelajaran, sedangkan yang kedua adalah cara yang digunakan untuk kegiatan pembelajaran. Kurikulum 2013 yang diberlakukan mulai tahun ajaran 2013/2014 memenuhi kedua dimensi tersebut.

\section{b. Rasional Pengembangan Kurikulum 2013}

Kurikulum 2013 dikembangkan berdasarkan faktor-faktor sebagai berikut:

\section{1) Tantangan Internal}

Tantangan internal antara lain terkait dengan kondisi pendidikan dikaitkan dengan tuntutan pendidikan yang mengacu kepada 8 (delapan) Standar Nasional Pendidikan yang meliputi standar isi, standar proses, standar kompetensi lulusan, standar pendidik dan tenaga kependidikan, standar sarana dan prasarana, standar pengelolaan, standar pembiayaan, dan standar penilaian pendidikan. Tantangan internal lainnya terkait dengan perkembangan penduduk Indonesia dilihat dari pertumbuhan penduduk usia produktif. Saat ini jumlah penduduk Indonesia usia produktif (15-64 tahun) lebih banyak dari usia tidak produktif (anak-anak berusia 0-14 tahun dan orang tua berusia 65 tahun ke atas). Jumlah penduduk usia produktif ini akan mencapai puncaknya pada tahun 2020-2035 pada saat angkanya mencapai $70 \%$. Oleh sebab itu, tantangan besar yang dihadapi adalah bagaimana mengupayakan agar sumberdaya manusia usia produktif yang melimpah ini dapat ditransformasikan menjadi sumberdaya manusia yang memiliki kompetensi dan keterampilan melalui pendidikan agar tidak menjadi beban.

2) Tantangan Eksternal

Tantangan eksternal antara lain terkait dengan arus globalisasi dan berbagai isu yang terkait dengan masalah lingkungan hidup, kemajuan teknologi dan informasi, kebangkitan industri kreatif dan budaya, dan perkembangan pendidikan di tingkat internasional. Arus globalisasi akan menggeser pola hidup masyarakat dari agraris dan perniagaan tradisional menjadi masyarakat industri dan perdagangan modern seperti dapat terlihat di World Trade Organization (WTO), Association of Southeast Asian Nations (ASEAN) Community, AsiaPacific Economic Cooperation (APEC), dan ASEAN Free Trade Area (AFTA). Tantangan eksternal juga terkait dengan pergeseran kekuatan ekonomi dunia, pengaruh dan imbas teknosains serta mutu, investasi, dan transformasi bidang pendidikan. Keikutsertaan Indonesia di dalam studi International Trends in International Mathematics and Science Study (TIMSS) dan Program for 
International Student Assessment (PISA) sejak tahun 1999 juga menunjukkan bahwa capaian anak-anak Indonesia tidak menggembirakan dalam beberapa kali laporan yang dikeluarkan TIMSS dan PISA. Hal ini disebabkan antara lain banyaknya materi uji yang ditanyakan di TIMSS dan PISA tidak terdapat dalam kurikulum Indonesia.

\section{c. Karakteristik Kurikulum 2013}

Kurikulum 2013 dirancang dengan karakteristik sebagai berikut:

1) mengembangkan keseimbangan antara pengembangan sikap spiritual dan sosial, rasa ingin tahu, kreativitas, kerja sama dengan kemampuan intelektual dan psikomotorik;

2) sekolah merupakan bagian dari masyarakat yang memberikan pengalaman belajar terencana dimana peserta didik menerapkan apa yang dipelajari di sekolah ke masyarakat dan memanfaatkan masyarakat sebagai sumber belajar;

3) mengembangkan sikap, pengetahuan, dan keterampilan serta menerapkannya dalam berbagai situasi di sekolah dan masyarakat;

4) memberi waktu yang cukup leluasa untuk mengembangkan berbagai sikap, pengetahuan, dan keterampilan;

5) kompetensi dinyatakan dalam bentuk kompetensi inti kelas yang dirinci lebih lanjut dalam kompetensi dasar matapelajaran;

6) kompetensi inti kelas menjadi unsur pengorganisasi (organizing elements) kompetensi dasar, dimana semua kompetensi dasar dan proses pembelajaran dikembangkan untuk mencapai kompetensi yang dinyatakan dalam kompetensi inti;

7) kompetensi dasar dikembangkan didasarkan pada prinsip akumulatif, saling memperkuat (reinforced) dan memperkaya (enriched) antarmatapelajaran dan jenjang pendidikan (organisasi horizontal dan vertikal).

\section{Metode Penelitian}

Penelitian ini pada dasarnya merupakan penelitian diskriptif, yaitu model penelitian untuk membuat paparan secara cermat terhadap fenomena sosial tanpa melakukan intervensi dan hipotesis. Metode penelitian menggunakan paradigma kualitatif.

\section{Lokasi penelitian}

Lokasi Penelitian di SD Negeri Purwantoro 1 dan MI Nurul Islam Tajinan.

\section{Responden penelitian}

Responden terdiri dari dua kelompok yaitu:

a. Dalam langkah awal untuk menyusun instrumen (panduan wawancara dan panduan observasi), informan yang dilibatkan dalam FGD adalah Tim dosen dan kepala sekolah

b. Untuk pengumpulan data lapang akan melibatkan guru kelas 1 dan 4 pada SD sampel yang menjadi sasaran penelitian.

\section{Tahapan penelitian}

Deskripsi kemmapuan guru ini diharapkan dapat mewadahi berbagai kondisi dan rentangan yang ada di SD SD Negeri Purwantoro 1 dan MI Nurul Islam Tajinan.Adapun tahapan penelitian seperti pada gambar berikut ini. 

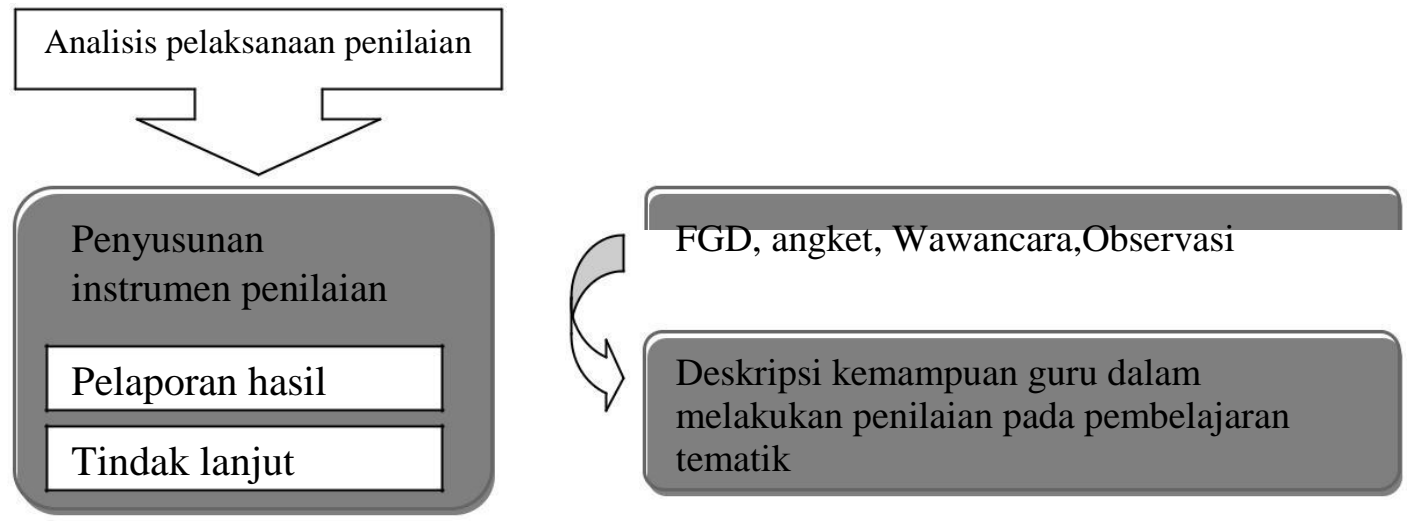

\section{Gambar 1. Tahapan Penelitian}

Secara garis besar metode pengumpulan data dalam penelitian ini menggunakan 4 (empat) metode yang digunakan secara simultan dan saling melengkapi, karena pada dasarnya masing-masing metode lebih cocok untuk mengumpulkan data tentang variabel tertentu dan akan saling melengkapi penggunaan metode pengumpulan data yang lain. Empat metode pengumpulan data tersebut adalah: Focus Group Discussion ( $F G D$ ) adalah penggunaan forum diskusi dalam kelompok yang anggotanya dibatasi kriteria tertentu dengan pembahasan yang dibatasi atau terfokus pada topik tertentu tanpa perlu kesepakatan bulat atau kesimpulan yang merupakan keputusan bersama. FGD dilakukan dalam dua tahapan yaitu:

1) gelar pendapat sebagai curahan pendapat dari ahli-ahli pendidikan di FKIP UMM akan menghasilkan materi dasar yang akan digunakan sebagai dasar pengembangan materi FGD dengan guru dan semua komponen sekolah, dan instrumentdalam penelitian ini berupa angket, panduan wawancara; dan

2) FGD dengan kepala sekolah dan guru di masing-masing sekolah (tiga kali FGD) untuk menggali data tentang berbagai permasalahan yang menyangkut penilaian pembelajaran tematik di sekolah tersebut.

Angket digunakan untuk mengetahui tingkat pengetahuan, keterampilan, sikap dan kesiapan guru dalam memahami penilaian, dan kemampuan guru dalam melakukan penilaian proses dan hasil belajarserta tindak lanjutnya. Wawancara yang digunakan adalah Indept Interview (wawancara mendalam) sesuai dengan permasalahan yang diungkap maka pengumpulan data akan bersifat konteks terfokus, dengan peneliti sebagai instrumen utama dibantu panduan wawancara akan dilakukan pada kepala sekolah dan guru pada tiap sekolah untuk melengkapi data angket, terutama dalam melengkapi aspek sikap guru. Wawancara dilakukan secara individual maupun diskusi bersama dengan guru dan KS. Observasi digunakan dalam mengidentifikasi permasalahan yang terkait dengan proses penilaian sekolah. Termasuk untuk melihat dokumentasi administrasi sekolah, dan informasi lain yang dianggap perlu untuk melengkapi data yang terkumpul dengan angket, wawancara maupun observasi.

\section{Teknik Analisis Data}

Data berhubungan dengan paparan perilaku dan pernyataan serta persepsi maka data yang pada umumnya berupa data kualitatif, sedang beberapa data yang berupa angka atau kuantitatif akan digunakan untuk melengkapi dan membantu pendiskripsian data kualitatif. Analisis yang digunakan berupa sajian secara 
kuantitatif untuk data-data yang dapat diangkakan, baik berupa prosentase, tabulasi frekuensi ataupun kross tabulasi, sedang data yang bersifat kualitatif yang tidak dapat disajikan secara klasifikatoris, akan disajikan dan dianalisis secara kualitatif sesuai dengan komponen permasalahan dan tujuan penelitian.

Analisis kualitatif yang dipilih adalah analisis fenomenologis dan pola kecenderungan dilakukan sepanjang waktu penelitian, secara garis besar dapat dijelaskan sebagai berikut:

Analisis data yang dilakukan sepanjang pelaksanaan penelitian yang meliputi:

a. Data hasil FGD akan langsung dirangkum di reduksi. Dengan analisis induktif maupun deduktif secara kualitatif, bersama-sama hasil kajian pustaka serta penelitian/ temuan terdahulu akan dapat ditetapkan indikator perilaku (persepsi, pengetahuan, sikap dan perilaku guru) dalam melaksanakan pembelajaran.

b. Dengan menggunakan lembar rangkuman dan lembar koding akan dapat diketahui informasi-informasi yang kurang jelas, kurang kontekstual ataupun data-data yang perlu diperdalam, difokuskan dan atau diulangi. Sumber data dari dokumentasi dan administrasi pembelajaran yang dimiliki sekolah akan melengkapi paparan data.

\section{Analisis data setelah pengumpulan data}

Setelah seluruh data terkumpul, dan dianalisis selama penelitian berlangsung; baik hasil angket yang telah dianalisis secara kuantitatif dan dimaknai sesuai tujuan penelitian,hasil observasi pembelajaran maupun wawancara yang dianalisis secara kualitatif. Maka akan dilakukan analisis akhir. Yaitu analisis semua rangkuman data yang telah memenuhi tujuan yang akan dicapai, kemudian dianalisis secara kontekstual dengan cara diolah sedemikian rupa sehingga akan dihasilkan satu gambaran bahasan dan pemaknaan sebagaimana diharapkan dalam tujuan penelitian (komponensial). Yang sangat bermakna dalam menyusun analisis tentang penilaian pada pembelajaran tematik di SD/MI Muhammadiyah Kota dan Kab.Malang sampel utamanya yaitu SDN Purwantoro I Kota Malang dan MI Nurul Islam Tajinan Kab. Malang.

Upaya untuk dapat memaparkan kemampuan guru dalam pelaksanaan penilaian pembelajaran tematikSDN Purwantoro I Kota Malang dan MI Nurul Islam Tajinan Kab. Malangdapat dilihat konsistensinya dengan metode yang digunakan, dengan mencermati bagan berikut :

\section{Alur Penelitian Tahun Pertama}

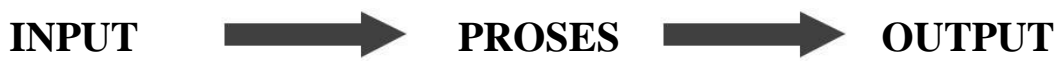

$$
\begin{aligned}
& \text { Mendeskripsikan kemampuan } \\
& \text { guru dalam } \\
& \text { 1. Penyusunan instrumen } \\
& \text { penilaian, } \\
& \text { 2. Pelaporan hasil penilaian, } \\
& \text { 3. Tindak lanjut penilaian. }
\end{aligned}
$$
1. FGD
2. Observasi
3. Angket
4. Wawancara

Deskripsi kemampuan guru dalam pelaksanaan penilaian pembelajaran tematikSDN Purwantoro I Kota Malang dan MI Nurul Islam Tajinan Kab. Malang 


\section{Hasil Penelitian dan Pembahasan}

\section{Hasil Penelitian dan pembahasan}

Penelitian ini dilaksanakan di kelas I dan IV di SDN Purwantoro 1 di jalan Letjen. S. Parman 67 Malang dan MI Nurul Islam Tajinan Kab. Malang. Dilaksanakan mulai bulan Nopember 2013 - Juli 2014. Sumber data dalam penelitian ini adalah guru kelas I dan kelas IV di SDN Purwantoro 1 Malang tersebut. Subyek penelitian di SDN Purwantoro I Kota Malang meliputi kelas I A IbuSri Yuniati, S.Pd dan Kelas I B IbuNanik Pujiastuti, S.Pd selanjutnya guru kelas IV meliputi kelas IVA IbuA. B. Sri Kusrini, S.Pddan kelas IV B BapakSlamet Wiyono, S.Pd. Sedangkan subyek penelitian di MI Nurul Islam Tajinan Kab. Malang yaitu Ibu Maruha dan Ibu Fitrotul Muafana.

Secara rinci penjelasan mengenai penyusunan instrumenpenilaian, model pelaporan hasil penilaian, tindak lanjut penilaian dan draf model penilaian pembelajaran tematik di SD Muhammadiyah Kota dan Kab. Malang akan dijabarkan sebagai berikut.

\section{Penyusunan Instrumen Penilaian dalam Pembelajaran Tematik di Kelas I dan Kelas IV. \\ Dalam penelitian ini dilakukan FGD serta observasi dan wawancara}

kepada subyek penelitian, khususnya di kelas 1 . Selain itu, untuk mendukung data yang diperoleh dilakukan studi dokumentasi dan pemberian angket. Hasil penelitian di SD Purwantoro 1 Kota Malang menunjukkan bahwa kurikulum 2013 telah dilaksanakan mulai tahun ajaran baru 2013/2014. Oleh karenanya, dalam hal penyusunan instrumen penilaian dalam pembelajaran tematik di kelas 1 telah dilakukan. Adapun pelaksananya adalah para guru MGMP di masing-masing gugus. Ada beberapa alasan yang disampaikan, diantaranya adalah karena selain kurikulum baru, juga ada beberapa alasan klasik yaitu tidak memiliki waktu dalam menyusun RPP setiap hari. Para Guru MGMP tersebut menggunakan buku pegangan siswa disesuaikan dengan tema pembelajaran dan menyusun instrumen penilaiannya berdasarkan buku tersebut. Serta tidak mendokumentasikan instrumen penilaian tersebut tetapi langsung digunakan saat kegiatan pembelajaran berlangsung.

Hasil dokumentasi dalam pelaksanaan komponen penilaian tersebut tidak ditemukan sumber datanya. Hal ini dijelaskan oleh Ibu Yuni mengatakan bahwa:

"Pelaksanaan komponen penilaian tersebut langsung diterapkan tidak didokumentasikan" (WT/Y/25 Mei 2014).

Penyusunan instrumen penilaian juga memperhatikan strategi penilaian. Subyek penelitian di kelas 1 menunjukkan telah melaksanakan strategi penilaian dengan menggunakan metode penilaian dan teknik penilaian. Metode Penilaian terdiri dari metode tes dan nontes. Hasil studi dokumentasi diketahui Ibu Yuni telah melaksanakan metode tes seperti seperti ulangan, tes lisan, UTS, UAS, UKK (D/Y/C6/25 Mei 2014) dan metode non-tes seperti penilaian perbuatan ditemukan datanya dalam buku penilaian (D/Y/C11/25-Mei 2014).

Berdasarkan hasil observasi di kelas Ib diketahui pendekatan penilaian yang digunakan adalah nilai kompetensi. Berdasarkan observasi pada tanggal 14 Mei 2014, tidak ditemukan dokumentasi mengenai belajar tuntas, otentik, berkesinambungan, berdasarkan acuan kriteria namun terdapat dokumentasi yang menggunakan teknik penilaian yang bervariasi yang ditemukan didalam RPP satu gugus (D/N/C4/25 Mei 2014). Penyusunan instrumen selanjutnya berdasarkan 
metode penilaian yang terdiri dari metode tes dan nontes. Hasil dari nilai instrumen penilaian tersebut tidak didokumentasikan sesuai dengan penilaian kurikulum 2013.

Selanjutnya, berdasarkan hasil penelitian di MI Nurul Islam Tajinan Kab Malang, diketahui bahwa pada saat dilakukan penelitian ini, sekolah dibawah naungan muhammadiyah ini belum melaksanakan kurikulum 2013. Lebih mendalam diketahui pula bahwa penilaian dilaksanakan salah satunya untuk memberikan remidi untuk para siswa yang nilainya kurang. Di sisi lain, hasil wawancara diketahui bahwa para guru belum pernah mengikuti pelatihan kurikulum 2013. Oleh karena itu, belum memiliki instrumen penilaian yang baku. Hal ini didukung ketidakaktivan para guru pada kegiatan di gugus.

Instrumen penilaian disusun berdasarkan pada LKS dan buku pegangan. Selain itu, dasar penyusunan adalah indikator pada setiap kompetensi dasar, pada setiap mata pelajaran. Selain itu, prinsip penilaian yang digunakan adalah obyektif, adil, terpadu, terbuka, menyeluruh dan berkesinambungan serta edukatif. Namun tidak ada bukti dokumentasi autentik mengenai instrumen yang didasarkan pada prinsip tersebut. Sedangkan kriteria penilaian adalah belajar tuntas, berkesinambungan dan menggunakan teknik penilaian yang bervariasi. Alasan penggunaan kriteria tersebut adalah kemampuan siswa yang berbeda-beda. Hasil pengejawantahan dari prinsip dan kriteria tersebut diwujudkan dalam bentuk tes tertulis dan penilaian portofolio. Meskipun demikian, pada saat diminta bukti dokumentasinya, para guru tersebut tidak mampu membuktikan.

Penjelasan selanjutnya adalah penyusunan instrumen penilaian yang dilaksanakan IV. Di SDN Purwantoro 1 Kota Malang, khususnya di kelas IVA diketahui tidak menyusun instrumen penilaian dalam pembelajaran tematik. Alasan yang disampaikan berdasarkan hasil wawancara menyatakan: "Tidak tahu karena belum pelatihan, disusun sesuai dengan Indikatorpembelajaran dan dikembangkan. (W/A/C2/13 Mei 2014)

Hasil dokumentasi tidak ditemukan data mengenai instrumen penilaian. Selanjutnya dalam komponen penilaian yang digunakan antara lain prinsip penilaian, pendekatan penilaian, dan karakteristik penilaian. Hasil dokumentasi tidak ditemukan komponen penilaian tersebut. Hal ini diperkuat dari pernyataan guru kelas yaitu Ibu Aster yang mengatakan bahwa:

"Sebelumnya guru kelas IVA kesehatannya tidak memungkinkan untuk melaksanakan tugasnya maka Ibu Aster menggantikan tugas di kelas IV A. (WT/A/C1/25 Mei 2014)

Penyusunan instrumen berikutnya yakni strategi penilaian. Hasil observasi pada tanggal 13 Mei 2014 diketahui telah melaksanakan strategi penilaian tersebut yang meliputi metode penilaian yang berupa tes dan nontes serta teknik penilaian. Metode dan strategi penilaian tersebut tidak didokumentasikan karena langsung diterapkan dalam pembelajaran di kelas.

Hasil observasi pada tanggal 13 Mei 2014 diketahui penyusunan instrumen penilaian berdasarkan muatan pelajaran serta RPP tematik. Hasil dokumentasi RPP yang dibuat sendiri oleh Bapak Slamet dengan menggunakan rubrik dan instrumen penilaian sebagai berikut.

Guru di kelas IVB ini juga menggunakan komponen penilaian dalam menyusun instrumen. Komponen penilaiannya antara lain prinsip penilaian, pendekatan penilaian, dan karakteristik penilaian. Hal ini diperkuat dari hasil wawancara menunjukkan bahwa semua prinsip penilaian antara lain sahih, 
objektif, adil, terpadu, terbuka, menyeluruh dan berkesinambungan, sistematis, beracuan kriteria, akuntabel, edukatif. Hasil observasi pada tanggal 13 Mei 2014diketahui bahwa tidak mendokumentasikan prinsip penilaian tersebut karena langsung diterapkan dalam menyusun instrumen penilaian. Komponen penilaian selanjutnya yakni, pendekatan penilaian.

Hasil analisis dokumentasi di atas, diketahui terdapat dokumentasi pengolahan nilai yang menggunakan nilai kompetensi. Nilai kompentensi tersebut meliputi nilai kompetensi sikap, nilai kompetensi pengetahuan dan nilai kompetensi keterampilan. Komponen penilaian berikutnya yakni karakteristik penilaian.

Berdasarkan hasil penelitian di MI Nurul Islam Tajinan Kab Malang, diketahui bahwa penilaian disusun untuk mencapai indikator. Selain itu, penilaian diharapkan dapat meningkatkan pemahaman siswa. Instrumen penilaian diberikan kepada peserta didik. Dan yang menjadi perhatian utama adalah aspek afektif. Di sisi lain, hasil wawancara diketahui bahwa para guru belum pernah mengikuti pelatihan kurikulum 2013. Oleh karena itu, belum memiliki instrumen penilaian yang baku.

Instrumen penilaian disusun berdasarkan pada LKS dan buku pegangan. Selain itu, dasar penyusunan adalah indikator pada setiap kompetensi dasar, pada setiap mata pelajaran. Selain itu, prinsip penilaian yang digunakan adalah obyektif, adil, terpadu, terbuka, menyeluruh dan berkesinambungan serta edukatif. Namun tidak ada bukti dokumentasi autentik mengenai instrumen yang didasarkan pada prinsip tersebut. Meskipun demikian, pada saat diminta bukti dokumentasinya, para guru tersebut tidak mampu membuktikan.

\section{Pelaporan Penilaian dalam Pembelajaran Tematik di Kelas I dan Kelas IV.}

Pada tahap pengambilan data mengenai pelaporan penilaian dalam pembelajaran tematik, peneliti melakukan observasi, wawancara dan dokumentasi di SDN Purwantoro 1 Malang dan MI Nurul Islam Tajinan pada kelas Idan kelas IV. Secara rinci, akan dijelaskan sebagai berikut.

Penyusunan pelaporan yang dilaksanakan di SDN Purwantoro 1 Malang pada kelas I diketahui telah menyusun pelaporan penilaian. Hal ini dikutip dari hasil wawancara yang menyatakan bahwa penilaian diperoleh dari rumus dan disusun narasi dalam bentuk rapor (W/Y/C14/14 Mei 2014). Sedangkan di kelas lainnya menyatakan bahwa rapor dikonversi dari rata-rata untuk mendapatkan prestasi perbidang studi dikonversi dalam bentuk pernyataan (W/N/C14/14 Mei 2014).

Hasil observasi pada tanggal 14 Mei 2014 didapatkan data tentang pelaporan penilaian. Pelaporan penilaian tersebut dalam bentuk deskriptif yang akan dituangkan di dalam penyusunan RPP.

Selain data di atas, untuk hasil telaah dokumentasi pelaporan penilaian pada tanggal 16 Juli 2014 diketahui pelaporan penilaian tersebut dalam bentuk berbagai jenis laporan. Jenis laporan tersebut antara lain laporan orang tua seperti rapor sisipan untuk UTS dan UAS. Sedangkan mengenai pelaporan penilaian di MI Islam Tajinan pada kelas 1, diketahui bahwa cara melakukan pencatatan perekaman hasil penilaian dengan cara mencatat nilai-nilai yang didapatkan dalam buku nilai. Adapun jenis pelaporan yang dibuat adalah penilaian UTS dan UAS. Hasil pelaporan tersebut kemudian dilaporkan kepada wali siswa, wali kelas dan 
kepala sekolah pada saat rapat guru mengenai penilaian pembelajaran dan setiap selesai UTS maupun UAS.

Data selanjutnya mengenai penyusunan pelaporan penilaian yang dilaksanakan dengan guru kelas IV di SDN Purwantoro 1 Malang, diketahui telah menyusun pelaporan penilaian.Hasil observasi diketahui jenis pelaporan yang digunakan yaitu menggunakan rapor sisipan dan rapor UAS. Hasil dokumentasi didapatkan dokumen pengolahan nilai dan penyusunan rapor (D/B/C10/25 Mei 2014).

Setelah melakukan pengolahan data dilanjutkan pelaporan penilaian, pada akhirnya para wali murid mendapatkan rapor. Hasil dokumentasi diketahui dalam penulisan rapor menggunakan tulisan tangan (D/B/C5/25 Mei 2014).

Proses yang hampir sama juga terjadi di MI Nurul Islam Tajinan, yang menyatakan juga bahwa rapor didapatkan setelah melakukan proses yang panjang dalm pembelajaran. Hasil pelaporan tersebut akan dilaporkan pada setiap pertemuan dengan wali siswa.

\section{Tindak lanjut Hasil Penilaian}

Sebagaimana proses pembelajaran yang dilakukan pada pembelajaran, eksplorasi kemampuan siswa secara kognitif, afektif maupun psikomotorik telah dilakukan maksimal di kedua sekolah ini. Namun demikian, kemmapuan siswa berbeda-beda. Maka kondisi yang terjadi adalah para siswa tidak $100 \%$ memenuhi ketuntasan KKM. Oleh karenanya perlu langkah-langkah tindak lanjut untuk terus mendapatkan hasil terbaik. Diantaranya adalah berusaha memberikan bimbingan ekstra serta melakukan penilaian yang berkesinambungan dan tuntas.

\section{E. Penutup}

\section{Kesimpulan}

Berdasarkan hasil penelitian dan pembahasan yang telah dipaparkan pada bab sebelumnya, dapat disimpulkan beberapa hal sebagai berikut. Penyusunan instrumen penilaian di kelas I dan kelas IV menggunakan komponen penilaian yang meliputi prinsip penilaian, pendekatan penilaian dan karakteristik penilaian. Prinsip penilaian yang digunakan di kelas I dan kelas IV meliputi sahih, objektif, adil, terpadu, terbuka, menyeluruh dan berkesinambungan, sistematis, beracuan kriteria, akuntabel, edukatif.Pelaporan penilaian dalam pembelajaran tematik di kelas I dan kelas IV disusun narasi dalam bentuk rapor yang terdiri dari nilai kompetensi pengetahuan, keterampilan, sikap dan spiritual. Selain itu, untuk tindak lanjut adalah pemberian bimbingan pada siswa yang belum mencapai ketuntasan belajar.

\section{Saran}

a. Guru dapat meningkatkan pemahaman terhadap kurikulum 2013 yang terdapat dalam buku panduan teknis penilaian di Sekolah Dasar tentang langkahlangkah penyusunan instrumen penilaian dalam pembelajaran tematik dan meningkatkan komponen penilaian serta strategi penilaian dalam menyusun instrumen penilaian.

b. Guru dapat meningkatkan dokumentasi rubrik dan instrumen penilaian dari hasil nilai belajar siswa dan dapat menggunakan berbagai teknik penilaian sesuai dengan kurikulum 2013.

c. Sebagai salah satu acuan untuk membuat kebijakan di sekolah, khususnya dalam penyusunan standar penilaian pada pembelajaran. 


\section{DAFTAR PUSTAKA}

Husamah dan Yanuar Setyaningrum. 2013. Desain Pembelajaran berbasis pencapaian kompetensi panduan merancang pembelajaran untuk mendukung implementasi kurikulum 2013. Malang: Prestasi Pustakaraya.

Kemendikbud.2012. Pengembangan Kurikulum 2013. Jakarta: Depdiknas.

Kemendikbud. 2012a. Kurikulum 2013. Bahan uji publik. Jakarta: Kementerian pendidikan dan kebudayaan.

Kemendikbud. 2013.Kompetensi Dasar Sekolah Dasar (SD)/Madrasah Ibtidaiyah (MI). Jakarta: Depdiknas.

Kemendikbud. 2013.Konsep Penilaian Autentik Pada Proses dan Hasil Belajar. Jakarta: Badan Pengembangan Sumber Daya Manusia Pendidikan dan Kebudayaan dan Penjaminan Mutu Pendidikan.

Kemendikbud. 2013. Panduan Teknis Penilaian di Sekolah Dasar. Jakarta: Kementerian pendidikan dan kebudayaan Direktorat jenderal pendididkan dasar Direktorat pembinaan sekolah dasar.

Kemendikbud. 2013a.Pengembangan Kurikulum 2013. Bahan sosialisasi kurikulum 2013 di Gresik Tanggal 19 Januari 2013.

Kemendikbud. 2014. Materi Pelatihan Guru Implementasi Kurikulum 2013 Tahun 2014 SD Kelas 1. Jakarta: Badan Pengembangan Sumber Daya Manusia Pendidikan dan Kebudayaan dan Penjaminan Mutu Pendidikan Kementerian Pendidikan dan Kebudayaan.

Kilpatrick, W. 1992. Moral Illiteracy. Chapter 6 in Why Johnny Can't Tell Right from Wrong and What We Can Do About It_. Edited by J.H. Clarke. New York: A Touchstone Book.

Kurikulum. 2013. Salinan Lampiran Permendikbud No. 67 th 2013 ttg Kurikulum SD. Jakarta: Depdiknas.

Kurniasih Imas dan Berlin Sani. 2014. Implementasi Kurikulum 2013: Konsep dan Penerapan. Surabaya: Kata Pena.

Mulyasa. 2013. Pengembangan dan Implementasi Kurikulum 2013. Bandung: PT Remaja Rosdakarya.

Permendikbud. 2013. Peraturan Menteri Pendidikan dan Kebudayaan No. 66 Tahun 2013 tentang Standar Penilaian. Jakarta: Depdiknas.

Permendikbud. 2013. Peraturan Menteri Pendidikan dan Kebudayaan No. 81A Tahun 2013 tentang Implementasi Kurikulum Pedoman Umum Pembelajaran.Jakarta: Depdiknas.

Permendikbud. 2013. Peraturan Menteri Pendidikan dan KebudayaanNomor 69 tahun 2013 tentangKerangka Dasar dan Struktur Kurikulum Sekolah Menengah Atas/Madrasah Aliyah.Jakarta: Depdiknas. 
Permendikbud. 2013. Peraturan Menteri Pendidikan dan Kebudayaan Republik Indonesia Nomor 66 Tahun 2013 tentang Standar Penilaian Pendidikan.Jakarta: Depdiknas.

Pusat Kurikulum. 2007. Naskah Akademik Kajian Kebijakan Kurikulum SD. Jakarta: Depdiknas.

Sadri, Ni Wayan. 2012. Studi Evaluasi Implementasi Pembelajaran Tematik Pada Sekolah Dasar Gugus I.Vol 1, No 2 (2011).

Sholihah, Helmiyatus.2013. Efektivitas Implementasi pembelajaran tematik oleh guru kelas II dan III SDN Tunggul Wulung 2 Malang.

Sisdiknas. 2003. Undang-Undang Republik Indonesia Nomor 20 Tahun 2003 tentang Sistem Pendidikan Nasional. Jakarta: Depdiknas.

Sukayati. 2004. Pembelajaran Tematik di SD Merupakan Terapan dari Pembelajaran Terpadu. Yogyakarta: PPPG Matematika-Depdiknas.

Supandi. 1992. Strategi Belajar Mengajar Pendidikan Jasmani. Jakarta: Depdikbud.

Trianto. 2010. Model Pembelajaran Terpadu. Surabaya: Bumi Aksara. 